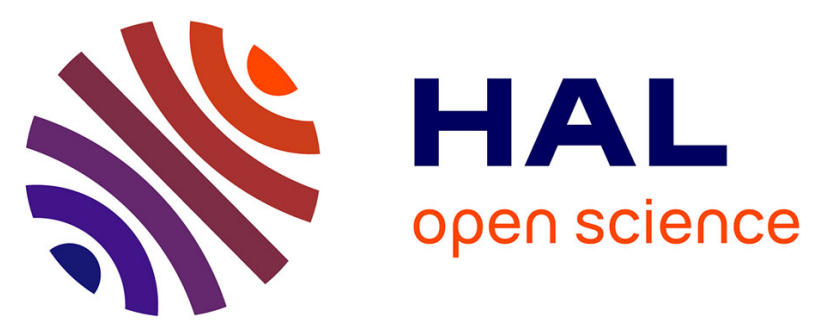

\title{
Inferring the agrobiodiversity of Vitis vinifera $L$. (grapevine) in ancient Greece by comparative shape analysis of archaeological and modern seeds
}

Clemence Pagnoux, Laurent Bouby, Sarah Ivorra, Christophe Petit, Soultana-Maria Valamoti, Thierry Pastor, Sandrine Picq, Jean-Frédéric Terral

\section{To cite this version:}

Clemence Pagnoux, Laurent Bouby, Sarah Ivorra, Christophe Petit, Soultana-Maria Valamoti, et al.. Inferring the agrobiodiversity of Vitis vinifera L. (grapevine) in ancient Greece by comparative shape analysis of archaeological and modern seeds. Vegetation History and Archaeobotany, 2015, 24, pp.75-84. 10.1007/s00334-014-0482-y . hal-02555863

\section{HAL Id: hal-02555863 https://hal.science/hal-02555863}

Submitted on 27 Apr 2020

HAL is a multi-disciplinary open access archive for the deposit and dissemination of scientific research documents, whether they are published or not. The documents may come from teaching and research institutions in France or abroad, or from public or private research centers.
L'archive ouverte pluridisciplinaire HAL, est destinée au dépôt et à la diffusion de documents scientifiques de niveau recherche, publiés ou non, émanant des établissements d'enseignement et de recherche français ou étrangers, des laboratoires publics ou privés. 


\title{
Inferring the agrobiodiversity of Vitis vinifera L. (grapevine) in ancient Greece by comparative shape analysis of archaeological and modern seeds
}

\author{
Clémence Pagnoux • Laurent Bouby • Sarah Ivorra • Christophe Petit • \\ Soultana-Maria Valamoti - Thierry Pastor $\cdot$ Sandrine Picq · Jean-Frédéric Terral
}

Received: 31 December 2013/Accepted: 9 August 2014

(C)

\begin{abstract}
The origins and biogeographical history of Vitis vinifera L. (domesticated grapevine) remain largely unknown. Shape and size have long been used as criteria to distinguish between wild and domesticated grape pips. Here we have analyzed variations of seed morphology in order to provide accurate criteria for the discrimination of different groups of varieties. Diversity in present-day cultivars and wild grapevines of Greek and east Mediterranean origin in relation to other Asiatic and European varieties and wild grapevines provides the basis for our analysis, which aims to allow the characterization of the ancient diversity of cultivated grapes in relation to present-day cultivars. Geometric morphometric analyses (Elliptic Fourier Transform method) have been used to characterize the seed shape and size of modern and archaeological material using 40 variables per seed. 197 archaeological grape pips from the 7th century ВС sanctuary of Hera in Samos, Greece were compared with an
\end{abstract}

Communicated by F. Bittmann.

Electronic supplementary material The online version of this article (doi:10.1007/s00334-014-0482-y) contains supplementary material, which is available to authorized users.

\section{Pagnoux $(\bowtie) \cdot$ C. Petit}

Université Paris 1 Panthéon-Sorbonne, UMR 7041, Maison de l'Archéologie et de l'Ethnologie, 21 allée de l'Université,

92023 Nanterre, France

e-mail: clemence.pagnoux@mae.u-paris10.fr

C. Petit

e-mail: christophe.petit@univ-paris1.fr

C. Pagnoux $\cdot$ L. Bouby $\cdot$ S. Ivorra $\cdot$ T. Pastor - S. Picq ·

J.-F. Terral

Centre de Bio-Archéologie et d'Ecologie, UMR 5059, Institut de botanique, 163 rue Auguste Broussonet, 34090 Montpellier, France

e-mail: laurent.bouby@univ-montp2.fr extended reference collection of 269 modern cultivars and 83 wild populations, 10,518 seeds in total. Our study confirms the relationships between seed shape and domestication. Modern diversity is partly structured by the geographical origin of cultivars, but influence of other factors may play a significant role in clustering. The wide diversity of varieties offered at the Heraion of Samos during the Archaic Period, including cultivars growing on the island, imported grapes and wild morphotypes, is related to the history and geographical location of the island as well as to the diversity in the geographical range of pilgrims making offerings to the sanctuary.

Keywords Grape pip morphology - Viticulture $\cdot$ Archaic Period · Archaeobotany · Diversity · Geometric morphometry

\section{Introduction}

The economic significance of viticulture as well as the symbolism of Vitis vinifera L. (grapevine) for many ancient

\author{
S. Ivorra \\ e-mail: ivorra@univ-montp2.fr \\ J.-F. Terral \\ e-mail: terral@univ-montp2.fr \\ S.-M. Valamoti \\ Department of Archaeology, Aristotle University of \\ Thessaloniki, 54124 Thessaloniki, Greece \\ e-mail: sval@auth.gr \\ J.-F. Terral \\ Université Montpellier 2, place Eugène Bataillon, \\ 34095 Montpellier Cedex 5, France
}


cultures has led to a proliferation of studies in the domains of biology, ecology, agronomy, agro-ecology, plant breeding, archaeology and history in the last decade (Smith and Jones 1990; Mangafa and Kotsakis 1996; Aradhya et al. 2003; Brun 2003, 2004; McGovern 2004; ArroyoGarcía et al. 2006; Bouby et al. 2006, 2010; Grassi et al. 2003; Margaritis and Jones 2006; This et al. 2006; Valamoti et al. 2007; Miller 2008; Myles et al. 2011; Bacilieri et al. 2013; Bouby et al. 2013; Lacombe et al. 2013; Picq et al. 2012).

Grapes were gathered from the wild already during Palaeolithic and Mesolithic times in many areas of the Near East and in the Mediterranean region (Hansen and Renfrew 1978; Zohary et al. 2012). Archaeological evidence of wine-making is the most ancient and substantial sign of a change in the nature of the use of grapes by humans. Based on chemical analyses, grape juice extraction and therefore probably wine making is reported in the 6th millennium $\mathrm{BC}$ in northern Iran (McGovern et al. 1996), in Georgia (McGovern 2004) and in Armenia about 4000 BC (Barnard et al. 2011). Archaeobotanical evidence of juice extraction from Dikili Tash in northern Greece (Valamoti et al. 2007) could suggest independent events of grapevine use or the spread of cultivars and know-how. However wine making and cultivation do not necessarily occur together. Wine could have been produced from wild grapes and, on the other hand, cultivation could have been begun for other reasons (Miller 2008). Yet, the Neolithic indications for wine making certainly correspond to early intensive use, management or incipient cultivation, but not necessarily leaving any morphological signs on the pips themselves (Renfrew 1995; Valamoti et al. 2007).

The possible contribution of local wild grapevines to the process of domestication outside the southwest Asian primary domestication area is still debated. Several studies of molecular diversity bear evidence of genetic relations between local wild grapevines and traditional cultivars in various areas of Europe. Such results are sometimes regarded as evidence of introgression from western wild germplasm into cultivars of eastern origin (Myles et al. 2011). On the other hand, some authors propose the existence of secondary domestication events at various places (Aradhya et al. 2003; Grassi et al. 2003; Arroyo-García et al. 2006).

Thus, despite the large amount of available information, the history of grapevine cultivation, the processes involved in its domestication and the underlying mechanisms remain to be elucidated. In particular, the timing, rhythms and rates of domestication that have contributed to establish an outstanding heritage of different varieties are largely unknown.

Vitis vinifera ssp. vinifera (domesticated grapevine) includes thousands of cultivars, which are classified according to their main uses, as wine, fresh fruit or dried raisins and sultanas. These cultivars derive from $V$. vinifera ssp. sylvestris (wild grapevine) (Zohary 1995; Sefc et al. 2000; This et al. 2006; Zohary et al. 2012), which is a heliophilous liana growing generally on river banks, and in alluvial and colluvial deciduous and semi-deciduous woods (Levadoux 1956; Arnold et al. 1998). Wild grapevine grows in an area ranging from western Europe to the Himalayas and around the Mediterranean basin. Its present distribution is highly fragmented, due to human activities and pathogens introduced from North America during the 19th century (Olmo 1995; Arnold et al. 1998).

According to classical ampelographic criteria (morphological criteria from different parts of the vine, such as leaves and fruits), three main eco-geographic groups of grape cultivars are defined (Negrul 1946; Levadoux 1956). The group Occidentalis is mostly composed of wine cultivars characteristic of western Europe; Orientalis includes mainly table cultivars from the Middle East and Near East; and Pontica is a group of cultivars from the area ranging from the Balkans to the Black Sea, which share characteristics with cultivars of the other two groups. Within each group, common morphological characteristics are recognized: cultivars clustered as Occidentalis have small fruits whereas Orientalis display bigger and oval fruits. This classification is today largely supported by genetic data, using microsatellite markers (Sefc et al. 2000; Aradhya et al. 2003; Bacilieri et al. 2013).

Seeds of wild and domesticated grapevine display dissimilarities which allow the discrimination between both subspecies: wild grapevine bears small and roundish seeds with short stalks, while pips from cultivars are more elongated, with longer stalks (Fig. 1). These morphological traits have been used to discriminate archaeological pips since Stummer's work (1911; Di Vora and Castelletti 1995; Mangafa and Kotsakis 1996; Jacquat and Martinoli 1999; Bouby and Marinval 2001; Terral et al. 2010; Bouby et al. 2013). The use of morphometrical criteria has been criticized because of the overlap between wild and domesticated seed shapes and because of seed deformation due to carbonization (Smith and Jones 1990; Renfrew 1995; Zohary 1995). Moreover, morphometric criteria and measurement values defined by Stummer (1911) and later by Mangafa and Kotsakis (1996) are based on a reference model which includes grape cultivars and wild individuals from a restricted area, which cannot be considered as representative of grapevine diversity (Bouby et al. 2006; Terral et al. 2010). Morphometrical analyses based on a large reference sample have shown that pips from wild and domesticated grapevine can be discriminated (Terral et al. 2010; Bouby et al. 2013; Orrù et al. 2013). A morpho-geometrical approach allows more exact identification, discriminating groups of varieties (Terral et al. 2010). It has been shown that the influence of environmental parameters is less on seed shape than on seed size. Furthermore, differences between cultivars are 


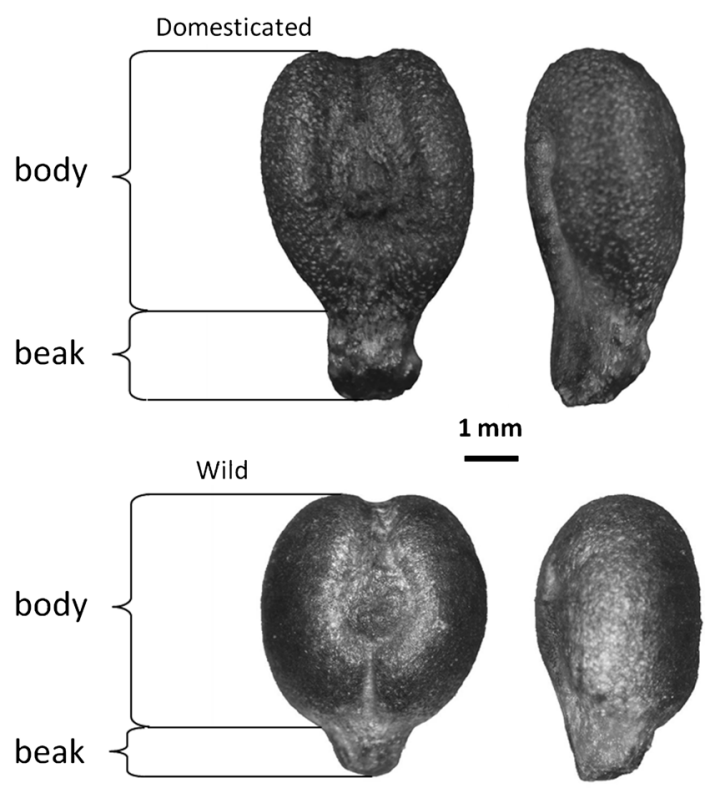

Fig. 1 Pips photographed in dorsal and lateral views, showing morphological dissimilarities in the shape and length of the stalk

significantly higher than variation due to environmental conditions (Terral et al. 2010, 2012). Consequently, this approach allows an accurate characterization of every cultivar using shape descriptors of pip outlines.

In light of these elements, the aim of this study is to investigate the diversity of cultivated grapevines in ancient Greece using shape analysis of seeds. We used a reference collection of modern pips which was larger than the one used in former studies (Terral et al. 2010; Bouby et al. 2013): we added 185 cultivated (cultivars) and 47 wild specimens, including a large number of wild and domesticated grapevines originating from central Europe, the eastern Mediterranean and south-west Asia (ESM 1). This allowed us to check whether wild and domesticated pips could still be discriminated at this large geographical scale, and to characterize diversity within wild and cultivated grapes. Particular attention was given to the organization of Greek cultivars in relation to local wild grapevines and to varieties from other regions. Then we applied the same morpho-geometrical method to archaeological pips in order to characterize their diversity compared to the modern reference collection. We considered waterlogged Vitis seeds from the sanctuary of Hera in Samos, Greece, dated to the 7th century BC. This archaeological site has provided plenty of waterlogged material and especially fruit remains and numerous wellpreserved grape pips (Kučan 1995, 2000). We used waterlogged remains because we postulate that waterlogged Vitis seeds have kept their original shapes, especially in comparison to charred remains. During the Archaic Period, Samos was a powerful city-state and a member of the Ionian League, which included city-states from the neighbouring islands and from Asia Minor. It was one of the important seafaring and trade centres in Greece. Indeed, the city-state had established trading colonies on the coast of Ionia, in Thrace, and even in the western Mediterranean. The island was thus in contact with areas located all around the Aegean Sea and due to its position near trade routes, it must have received various influences (Shipley 1987). During the Archaic Period in the Aegean, cultivation of the grapevine was already under way, probably having started in the Bronze Age or even earlier (Renfrew 1995). At the same time, Greek cities imported wine from other regions and also exported their products to the Near East, Egypt and Italy (Foxhall 1998). At that time, several cities or regions, especially the eastern Aegean islands, became famous for their wine (Brun 2003, 2004).

\section{Materials and methods}

\section{Modern reference material}

The modern reference material used in this study consisted of pips from 269 European and Mediterranean cultivars (ESM 1) and from 83 wild grapevines (ESM 2). We selected cultivars which are reported in the literature to be typical of the regional viticulture during recent centuries in Greece, Italy, Turkey, Romania, Bulgaria, Cyprus and also from central and western Europe, from the Caucasus area, south-west Asia and also North Africa (Lacombe 2012). Their main characteristics are given in ESM 1. This procedure intends to give the best image of the modern diversity among cultivars. All the cultivars have been sampled in the INRA Grape Germplasm Repository of Domaine de Vassal, Marseillan, France (http://www.1. montpellier.inra.fr/vassal). Whenever possible, the grapes were sampled from a single plant, but when the number was considered insufficient, further sampling was carried out from the neighbouring plants, which were in fact clones of the first specimen. This procedure was carried out for each cultivar.

Wild populations were collected from natural conditions in France, Spain, Italy, Greece, Turkey and Georgia, in order to cover the area where wild grapevine grows spontaneously. Generally it has been possible either during sampling or during former field trips or from the literature to assess that the sampled populations were composed of male and female plants. One of the main differences between wild and domesticated grapevine is related to sex: wild individuals are dioecious while most of the cultivars are hermaphrodite (Levadoux 1956; This et al. 2006; Picq 2012; Picq et al. 2012). However, it is not possible to 
ensure that there are only truly wild grapevines in our sample. Feral forms originating from seeds may also be present.

This wide set of references aims to be a representative sample of modern-day wild and domesticated grapevines.

\section{Archaeological material}

The archaeological plant remains came from a rectangular basin located in the southern part of the sanctuary which contained many well-preserved plant remains, which were associated with other finds of ceramics and wooden objects probably linked to the cult of Hera. Among the botanical material, numerous fruit remains were recovered, including typical Mediterranean species, Prunus dulcis (almond), Ficus carica (fig), Punica granatum (pomegranate), Olea europaea (olive) and V. vinifera (grape) as well as fruits possibly imported from regions further east, Citrullus lanatus (watermelon), Prunus persica (peach) and Morus nigra (black mulberry) (Kučan 1995, 2000). More than 2,000 grape pips were recovered. Among them, 197 whole and mature seeds, displaying no obvious deformation, were selected from samples rich in grape seeds for analysis.

\section{Shape analysis of seed outline}

The shapes of the seeds were studied using outline analysis based on the Elliptic Fourier Transform (EFT) method. According to the method developed by Terral et al. (2010, 2012), 30 seeds per modern individual (cultivars and wild individuals) and the 197 archaeological seeds were photographed in dorsal and lateral views (Fig. 1). Each seed was placed on modelling clay to be photographed. For seven wild individuals fewer than 30 pips were available (ESM 2). Using an image analysis system, 64 points were automatically and regularly positioned on each outline. Coordinates of those points were extracted and analysed by the EFT method under R software v2.13 (R Development core team 2011) using the Momocs package (Bonhomme et al. 2014). This method is based on the separate Fourier decomposition of the incremental changes of the $x$ and $y$ coordinates as a function of the cumulative length along the outline (Kuhl and Giardina 1982). Each harmonic function corresponds to four coefficients defining an ellipse. The coefficient of the first harmonic is used to standardize seed size and orientation. According to Terral et al. (2010), five harmonics per outline (H2, H3, H4, H5 and H6) are considered, in order to optimize the efficiency of shape reconstruction and minimize measurement errors. Finally, EFT provided 40 coefficients (20 for both dorsal and lateral outlines) which could be used as quantitative variables in multivariate statistical analyses.
Number of seeds required for an optimal evaluation of shape variation

The sampling effort, the number of seeds to be used for an optimal evaluation of shape variation at the individual level, was assessed using principal component analysis (PCA) applied on 40 pips from one cultivar (Kypreiko) and 40 from one wild individual (Venetikos 14), and on the quantitative shape parameters retained during the preliminary analytical phase. The coordinates of the pip point cloud centroid (the consensus individual) in the multivariate PCA space were determined. Shape variation was then estimated by computation of the cumulative dispersion of points, from the first to the 40th, around the variety or wild individual centroid, and expressed as the mean distance separating each point from the centroid. The minimum number of points necessary for an optimal evaluation of shape variation at the individual level is estimated when the dispersion index reaches an asymptotic value.

Statistical analyses

Linear Discriminant Analysis (LDA) was performed on 10,518 seeds in order to test morphological differentiation between modern groups. The aim of the LDA is to evaluate the morphological variability of pips by maximizing differences between predefined groups ( 83 wild and 269 varieties) compared to the intra-group variation. This multivariate statistical method quantifies geometric differences between each of the wild grapes and varieties using a dissimilarity distance matrix and then tests their discrimination. Additionally, in order to interpret relationships among wild populations and cultivars, an UPGMA (unweighted pair group method with arithmetic mean) clustering analysis was performed using the Mahalanobis distance matrix between the centroids of wild and domesticated individuals. Statistical analyses were performed using $\mathrm{R}$ software $\operatorname{lda}()$ and $\operatorname{dist}()$ functions. This method allows identification of groups of modern individuals which are closely related according to their seed shape. Then archaeological seeds were compared to the reference sample as additional observations in the LDA in order to be assigned to a specific group with a probability of allocation. We considered the allocation reliable if $\mathrm{p} \geq 0.75$, and very accurate if $\mathrm{p} \geq 0.9$.

\section{Results}

Number of seeds required for an optimal evaluation of intra-individual shape variation

Shape variation of Kypreiko and Venetikos 14 evaluated by calculation of a dispersion index for an increasing number of 
pips (from 1 to 40 seeds) was constant from 23 to 25 pips (Fig. 2). Thus, we consider that inter-individual shape variation can be accurately assessed using 30 seeds per individual.

\section{Reference material}

The plot of the centroids of modern wild individuals and varieties on the first two axes of the LDA (explaining $38.08 \%$ of the total variance) shows an obvious discrimination between wild and domesticated grapes. Overall, $95.79 \%$ of the pips are correctly re-assigned $(98.04 \%$ for domesticated and $88.39 \%$ for wild) (Fig. 3a).

In the UPGMA dendrogram, the branches are coloured according to subspecies (wild vs. domesticated) and to the

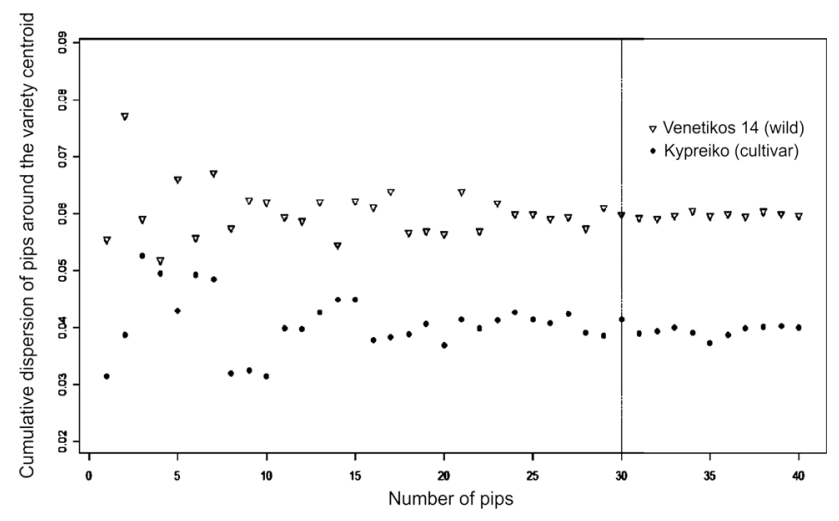

Fig. 2 Evaluation of the number of pips to be used for an optimal evaluation of shape variation at the individual level assessed using principal components analysis (PCA) applied on 40 seeds of 'Kypreiko' variety and 'Venetikos 14 ' wild grape. Shape variation was appraised by computation of the cumulative dispersion of points, from the first to the 40th, around the individual centroid, calculated as the mean distance separating each point from the centroid. From 23 to 25 pips (level indicated by a dotted line), shape variation appears to be negligible but 30 pips were considered for more security putative geographical origin of the cultivars, each colour corresponding to a geographical area as defined in Table 1 . 15 main groups and various sub-groups are distinguished (Fig. 4). The unrooted cluster tree confirms the strong discrimination between cultivars and wild grapevines. Wild grapevines are all clustered in Group 1, together with eight cultivars (in Groups $1 \mathrm{~B}, 1 \mathrm{~F}$ and $1 \mathrm{G}$ ), except three individuals clustered with cultivars in Group 8. Most of the cultivars are clustered in 14 groups. The morphological diversity seems therefore higher in the domesticated group than among wild plants. Most of the groups and sub-groups contain cultivars from various countries. Greek cultivars are clustered in groups composed of cultivars from the Balkans, Caucasus and western Europe (3B, 5B, 9B, 13, 14). They are associated with varieties from Italy in Groups 5B, 7B and 9C, and with cultivars from the Maghreb, Near East and other origins in Groups 5B, 9C and 12.

\section{Archaeological pips}

Regarding the archaeological material, 131 pips can be assigned to one of the UPGMA clusters $(p \geq 0.75)$ (Figs. 5, 6, ESM 3). 102 pips can be assigned to a modern individual $(\mathrm{p} \geq 0.75)$, including 86 at a high probability (p $\geq 0.9$ ) (Fig. 6, ESM 4). Most of them are allocated to domesticated forms $(n=81)$. They are mostly assigned to groups clustering cultivars from Greece, the Caucasus, the eastern Mediterranean and the Balkans (Groups 3B, 9B, 9C, 7B, 8) (ESM 3). 39 pips are specifically allocated to Greek and Turkish varieties and to one Bulgarian cultivar, which is clustered with some Greek and Turkish varieties (ESM 4). 20 seeds are assigned to Groups $1 \mathrm{~F}$ and $1 \mathrm{G}$, which include wild grapevines but also some cultivars. 30 seeds are allocated to Groups $1 \mathrm{D}$ and $1 \mathrm{H}$, mostly composed of wild grapevines. 66 seeds cannot be classified, possibly
Fig. 3 Linear discriminant analysis plot of axes 1 and 2 explaining $38.08 \%$ of total variance. $3 \mathrm{a}$, the centroid of each cultivar or wild accession is represented. Cultivated varieties and wild grapevines are discriminated according to the EFT method. 3b, each archaeological pip and the centroid of the archaeological sample are represented

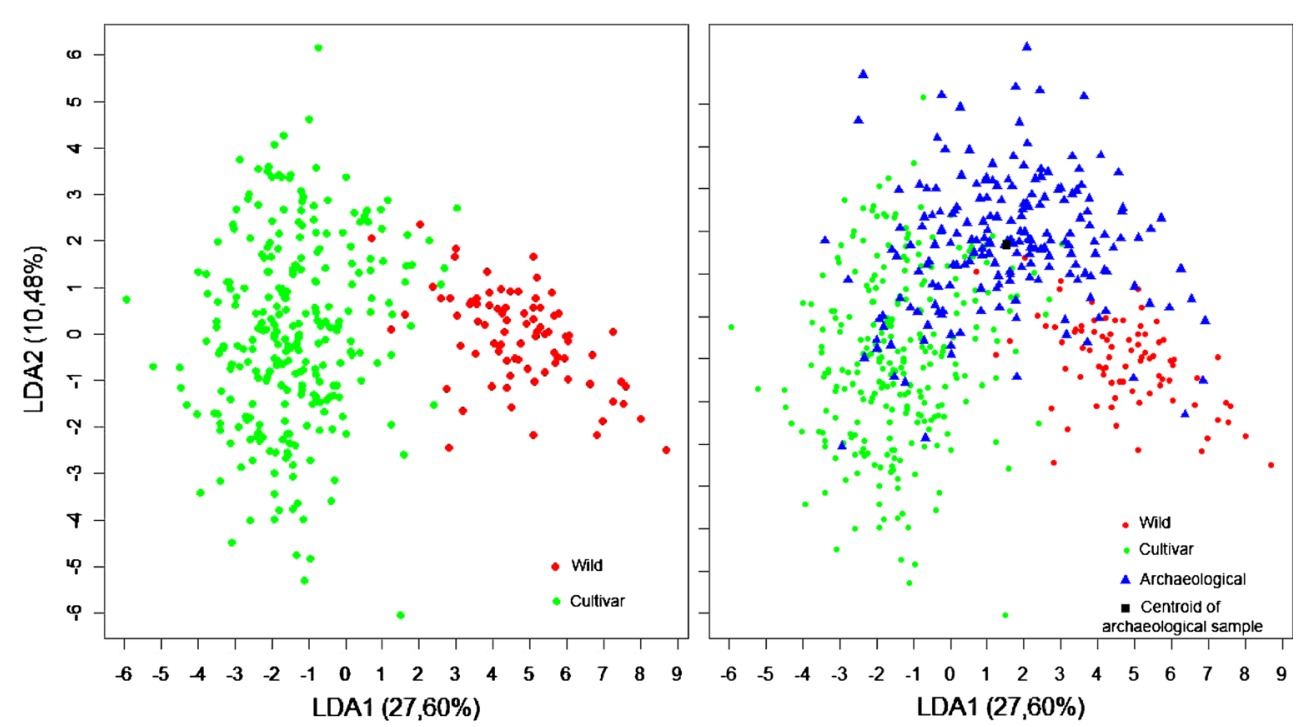


Table 1 Geographical origins of the cultivars used in our reference collection

\begin{tabular}{llc}
\hline Geographical area & Countries & No of cultivars \\
\hline Greece & Greece & 51 \\
Balkans & Cyprus, Croatia, Romania, Bulgaria, Hungary & 40 \\
Italian Peninsula & Italy & 29 \\
Western and central Europe & France, Germany, Switzerland, Austria, Czech Republic & 58 \\
Iberian Peninsula & Spain, Portugal & 10 \\
Maghreb and Near East & Algeria, Egypt, Morocco, Tunisia, Syria, Lebanon, Israel & 11 \\
Caucasus & Turkey, Georgia, Azerbaijan, Armenia & 47 \\
Middle East, central Asia, Russia & Afghanistan, Iran, Russia & 9 \\
New world & USA, California & 1 \\
Non determined (ND) & Non Determined & 13 \\
\hline
\end{tabular}

because no modern analogue is available in the reference model. They may correspond to morphotypes that have not been sampled or to extinct cultivars, but they may also be damaged or deformed pips, despite our cautious selection.

\section{Discussion}

Diversity of current varieties indicated by the evidence of distinct morphotypes

Wild grapevines are clearly distinct from cultivars on the basis of their seed shape. This confirms previous results from shape analysis (Bouby et al. 2010; Terral et al. 2010) as well as from traditional morphometric analysis (Bouby and Marinval 2001; Bouby et al. 2013). Our results confirm the efficiency of the morpho-geometrical approach in discriminating morphotypes within the domesticated material.

From wild to domesticated, grape pips clearly display a phenotypic differentiation which consists of the elongation and the enlargement of the stalk, which is the basal part of the seed which is attached to the placenta. This morphological change may be considered as a sign of domestication. As we analysed pip outlines by standardizing size, we may assert that changes in seed shape are related to domestication, even if shape was probably not a direct target of selective pressures. The shape is more probably connected to other characters which may have been selected, such as size or shape of the grapes. A correlation between grape size, number of seeds per grape and seed shape has been shown in wild grapes, suggesting the existence of an allometric relationship between size and shape, so that larger grapes have more elongated pips with longer beaks (Picq 2012; Bouby et al. 2013).

Furthermore, diversity of grape size and shape is stronger in the domesticated than in the wild material. This could explain the more homogeneous seed shapes in wild grapes than in domesticated forms. The morphological homogeneity of wild grape pips can be explained by differences in the type and intensity of selective pressures. In the wild grapevine, seed morphology is essentially subject to natural selection and developmental factors, while in the domesticated grape, morphological diversity reflects the strong constraints which occurred during its long evolutionary history, with human selection, diffusion, hybridization, adaptation etc. Grape size and shape have clearly been the target of repeated human selection during the process of domestication and diversification of the grapevine, according to diverse and changing needs related to uses, such as table versus wine varieties and tastes, and a complex historical biogeography.

There is no clear structure of cultivars according to their geographical origin. Generally, the groups (or morphoclades) are composed of cultivars from various origins but they often cluster together cultivars from nearby regions.

Greek cultivars are for example more commonly found in some of the groups. Many of them are encountered in groups composed of cultivars from the Balkans, the Caucasus and western Europe, but they are less closely related to varieties from Italy and from the Near East and the Maghreb. Therefore a tendency exists for Greek cultivars to be associated with cultivars from neighbouring eastern and western regions. This is of course consistent with the geographical location and history of Greece, which received throughout its history influences from east and west and has played a key role in the diffusion of crop plants toward western areas. We can therefore suppose that seed morphological similarities partly reflect common phylogeographical origins. In order to test this hypothesis, it would be necessary to consider the parentage relationships between cultivars rather than their supposed geographical origins. Inheritance of nuclear microsatellite markers shows that many modern cultivars result from crosses between parents from different geographical origins (Lacombe et al. 2013). For example, many varieties from the Balkans have been crossed with eastern and western European cultivars. 


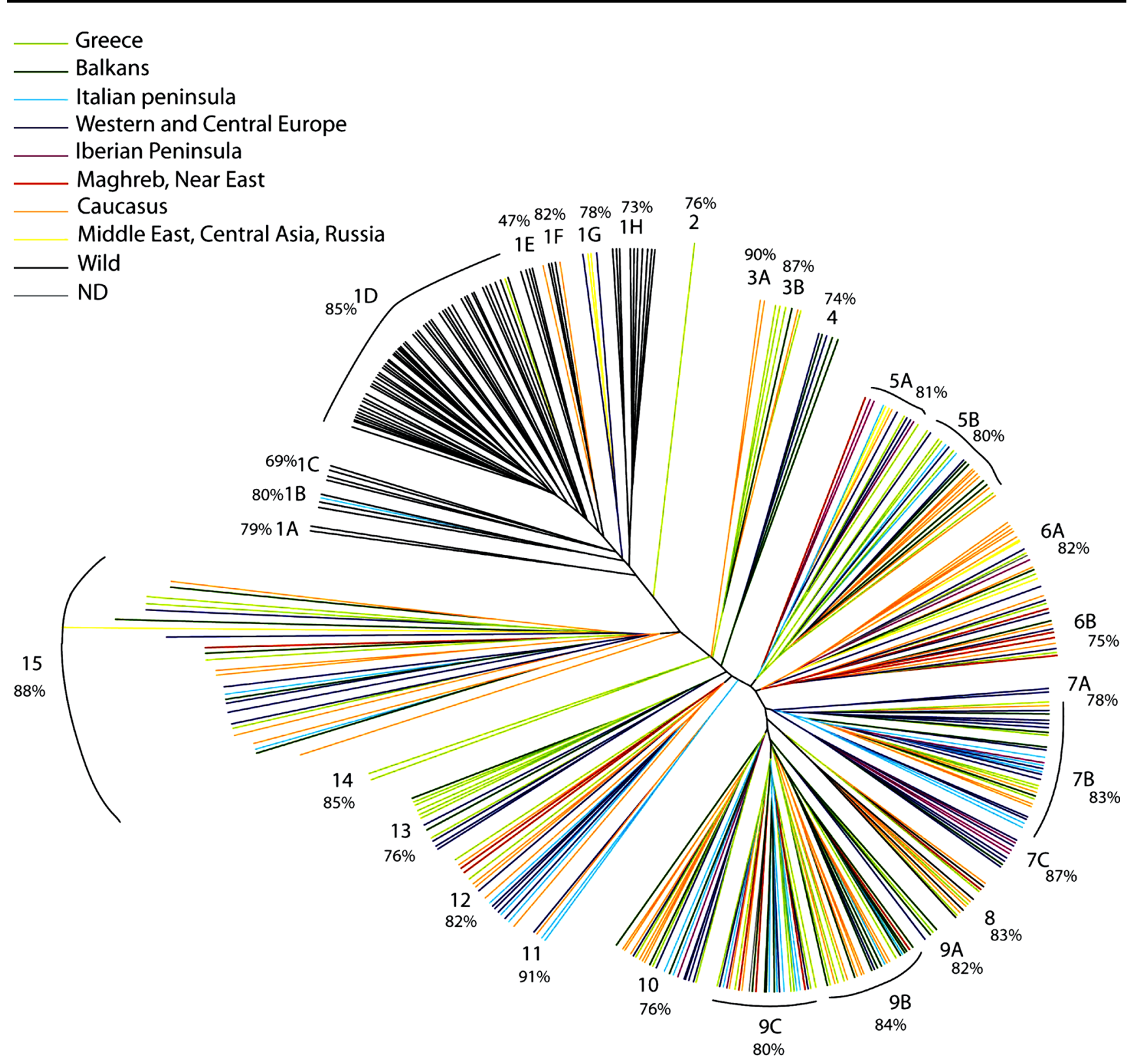

Fig. 4 UPGMA dendrogram based on Mahalanobis distance among wild grapevine individuals and cultivars. The discrimination value for each group or sub-group is presented

Archaeological grape pips: a wide diversity ranging from wild to modern domesticated morphotypes

The archaeological seeds examined here have been allocated to many cultivars and wild individuals, which is consistent with the context they come from. The function of the basin is not clear. The variety of debris found may imply that the first use of the basin was later replaced by its use as rubbish dump. It contains objects linked with the cult of Hera, but they do probably not reflect one single event. As for every kind of remains, the grape pips probably do not constitute a homogeneous assemblage coming from a specific use. Archaeological samples from Samos originate from several events, therefore probably involving various varieties from various origins.

Most of the grape pips from Samos have been allocated to 31 cultivars (Fig. 5, ESM 4), but they do not cover the whole range of domesticated morphotypes. The seeds allocated to Greek, Turkish and Bulgarian varieties may be evidence of local cultivars, whether they were introduced from nearby areas in mainland Greece, the Aegean islands and Asia Minor, or even domesticated on the island of Samos.

Some archaeological seeds have been allocated to varieties from Azerbaijan $(\mathrm{n}=5)$, Georgia $(\mathrm{n}=3)$ and 


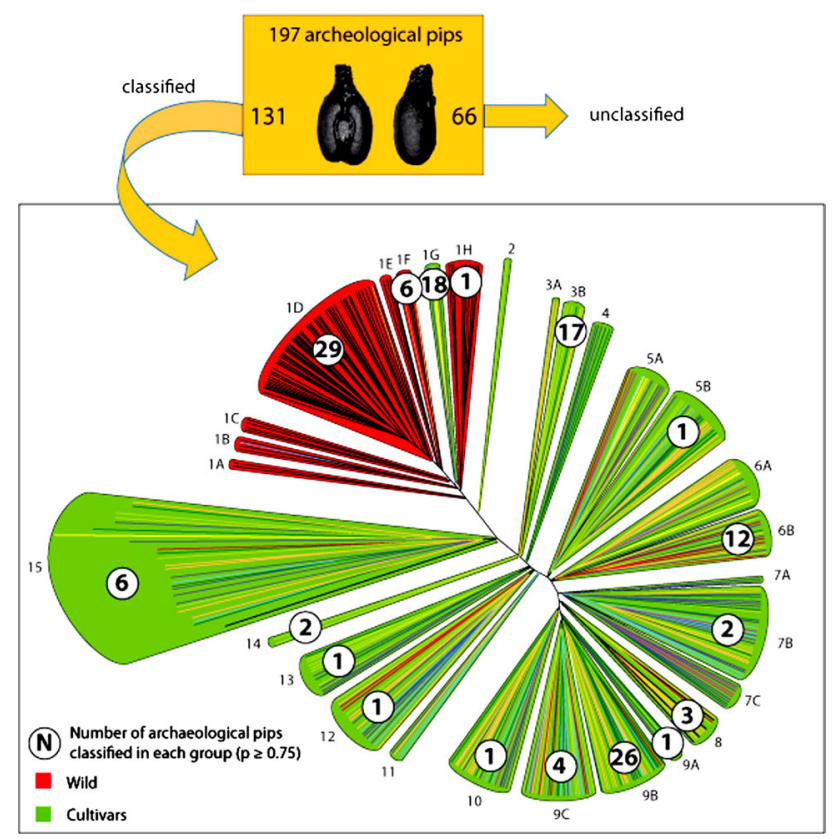

Fig. 5 Number of archaeological pips allocated to the groups defined by UPGMA cluster analysis; the dendrogram is based on Mahalanobis distances among grapevine wild individuals and cultivars

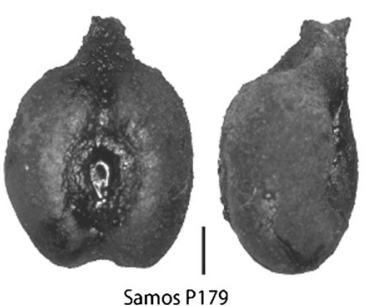

Allocated to wild morphotype, group $1 D$

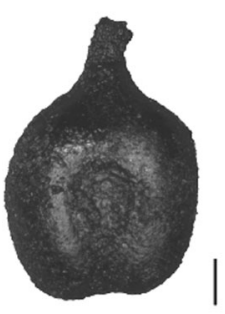

Samos P39

Allocated to cultivar (Haimka), group $9 B$

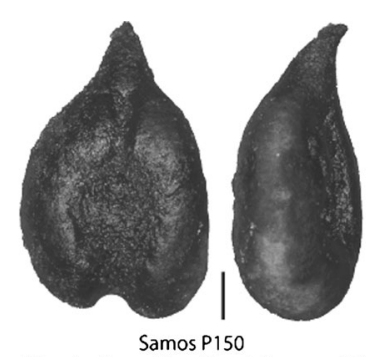

Allocated to cultivar (Agadai), group $1 \mathrm{G}$

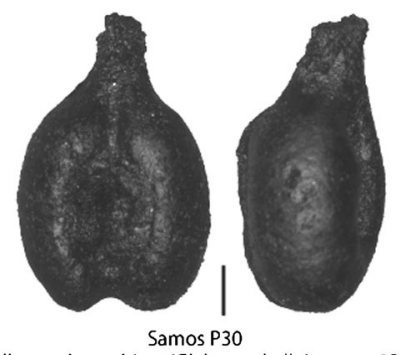

Allocated to cultivar (Glykostaphyllo), group 3B
Fig. 6 Examples of archaeological seeds allocated to the most frequent morphotypes; scale bar $=1 \mathrm{~mm}$

Afghanistan $(n=2)$, corresponding to some of the areas where grapevine may have been first domesticated. These seeds may reflect the arrival of varieties from the Caucasus in Samos, at some time between the Neolithic and the Archaic periods. At that time, grapes, grapevine shoots or grafts may also have been imported to Samos, especially as the sanctuary was frequented by pilgrims from Asia Minor, and as the island was in contact with the Aegean world and the Near East. For that matter, several products recovered from the archaeological site are considered as evidence of possible imports, such as plant species from eastern regions, pottery from Cyprus and Greece and animals or their products/remains from Egypt or the Near East (Shipley 1987; Kučan 1995, 2000).

Some archaeological pips may correspond to "less selected" primitive cultivars, morphologically close to wild grapevines. This is the case for pips allocated to cultivars from central Asia (Georgia, Daghestan, Russia) and western Europe $(n=16)$ found in Groups $1 F$ and $1 G$, which are part of the wild grapevines cluster, and for those assigned to Group $1 \mathrm{G}(\mathrm{n}=4)$ These "primitive cultivars" may have been domesticated locally or introduced from elsewhere.

The seeds allocated to wild individuals and to Groups $1 \mathrm{D}$ and $1 \mathrm{H}$, mostly composed of wild grapevines $(\mathrm{n}=30)$, may be the remains of grapes gathered in the wild: grapes are known to have been gathered in Greece in the Neolithic period (Renfrew 1966, 1989; Sarpaki 1995). It may be assumed that several plants identified in the Heraion assemblage are evidence of the gathering of wild fruits, especially Myrtus communis, Rosa sp., Rubus fruticosus and Pistacia terebinthus. Thus, wild grape may also have been gathered in the wild and consumed as an offering in the sanctuary. However, as previously suggested by Bouby et al. (2010) and Valamoti et al. (2007), wild grapevine cultivation cannot be excluded. Cultivation of "morphologically" wild grapevine is known in several places, especially in Roman wine-producing and urban sites in southern France (Bouby et al. 2010, 2013; Figueiral et al. 2010, 2014; Terral et al. 2010). Wild morphotypes could also correspond to "primitive cultivars", which had not sustained strong selective pressure.

\section{Conclusion}

Morphometric analyses applied to modern grape pips from various geographical areas allow us to characterize grapevine diversity. Wild grapes are clearly distinguished from cultivars, and the cultivated grapes are characterized by a wide diversity. This diversity is only partly structured according to the geographical origin of cultivars. However, the clustering of cultivars is far from being a simple image of their supposed geographical origins. Other biological characteristics are probably involved.

Shape diversity of the archaeological grape pips suggests the use of different grape varieties in the sanctuary. The pips recovered from the Heraion are probably evidence of viticulture carried out in Samos involving several varieties, ranging from wild grapevine or less selected to highly selected cultivars. Moreover, there are probably 
extinct and intermediate forms among grape pips which could not be classified as current cultivars (95 seeds), which is also evidence of the past diversity of grapevines involved in the economic and symbolic activities of Samos. This diversity is consistent with the period and the location of the island. In the 7th century BC, grapes had already been under cultivation for four millennia, and Samos was in contact with the whole Aegean world and probably with the Near East. Exchanges and, possibly, local experimentations must therefore have led to a high level of grapevine diversity. In addition to locally cultivated grapes, wild grapes could also have been gathered and offered. Fruits from other areas may have been imported, especially since other possibly imported fruit were recovered in the sanctuary. Moreover, such a sanctuary must have brought people from Asia Minor to Samos who may have imported products from eastern areas as offerings.

In further studies, material from other archaeological sites must be studied in order to understand the evolution and the geographic variation of Greek grapevine diversity more precisely. Moreover, comparisons with archaeological seeds from other areas may offer new insights into the history and spread of grapevine cultivation and domestication.

Acknowledgments We would like first to acknowledge Thierry Lacombe (INRA) who has been of great help in selecting the historical cultivars to include in our reference collection. We are grateful to INRA Domaine de Vassal (Marseillan, France) which provided pips from modern wild grapevines and cultivars, and especially to Sandrine Lalet (INRA) who helped during sampling. We are grateful to Dušanka Kučan and Felix Bittmann (Niedersächsisches Institut für historische Küstenforschung, NIhK) who gave access to the archaeobotanical material. We thank the referees for useful and constructive comments.

\section{References}

Aradhya MK, Dangl GS, Prins BH, Boursiquot JM, Walker MA, Meredith CP, Simon CJ (2003) Genetic structure and differentiation in cultivated grape, Vitis vinifera L. Genet Res Camb 81:179-192

Arnold C, Gillet F, Gobat JM (1998) Situation de la vigne sauvage Vitis vinifera ssp. silvestris en Europe. Vitis 37:159-170

Arroyo-García R, Ruiz-García L, Bolling L, Ocete R et al (2006) Multiple origins of cultivated grapevine (Vitis vinifera L. ssp. sativa) based on chloroplast DNA polymorphism. Mol Ecol $15: 3,707-3,714$

Bacilieri R, Lacombe T, Le Cunff L, Di Vecchi-Staraz M, Laucou V, Genna B, Peros JP, This P, Boursiquot JM (2013) Genetic structure in cultivated grapevines is linked to geography and human selection. BMC Plant Biol 2013:13-25

Barnard H, Dooley AN, Areshian G, Gasparyan G, Faull KF (2011) Chemical evidence for wine production around $4000 \mathrm{BCE}$ in the Late Chalcolithic Near Eastern Highlands. J Arch Sci 38:977-984

Bonhomme V, Picq S, Gaucherel C, Claude J (2014) Momocs: outline Analysis using R. J Stat Software 56:1-24

Bouby L, Marinval P (2001) La vigne et les débuts de la viticulture en France : l'apport de l'archéobotanique. Gallia 58:13-28
Bouby L, Terral JF, Ivorra S, Marinval P, Pradat B, Ruas MP (2006) Vers une approche bio-archéologique de l'histoire de la vigne cultivée et de la viticulture : problématique, choix méthodologiques et premiers résultats. Archéologie du Midi Médiéval 23-24:61-74

Bouby L, Terral JF, Figueiral I, Ivorra S, Lacombe T, Pastor T, Picq S, Buffat L, Fabre L, Jung C, Marinval P, Petitot H, Tardy C (2010) La vigne sauvage (Vitis vinifera subsp. sylvestris) : une plante cultivée dans les établissements viticoles de Narbonnaise ? In: Delhon C, Théry-Parisot I, Thiébault S (eds) Des Hommes et des plantes. Exploitation du milieu et gestion des ressources végétales de la Préhistoire à nos jours. XXXe rencontres internationales l'archéologie et d'histoire d'Antibes. APDCA, Antibes, pp 129-139

Bouby L, Figueiral I, Bouchette A, Rovira N, Ivorra S, Lacombe T, Pastor T, Picq S, Marinval P, Terral JF (2013) Bioarchaeological insights into the process of domestication of grapevine (Vitis vinifera L.) during Roman time in Southern France. PLoS ONE 8:e63195. doi:10.1371/journal.pone.0063195

Brun JP (2003) Le vin et l'huile dans la Méditerranée antique. Errance, Paris

Brun JP (2004) Archéologie du vin et de l'huile. De la préhistoire à l'époque hellénistique, Errance

Di Vora A, Castelletti L (1995) Indagine preliminare sull'archaeolgia della vite (Vitis vinifera L.) in base ai caratteri diagnostici del vinacciolo. Riv Archaeol dell'Antica Prov e Dioc di Como 176:333-376

Figueiral I, Bouby L, Buffat L, Petitot H, Terral JF (2010) Archaeobotany, vine growing and wine producing in Roman Southern France: le site of Gasquinoy (Béziers, France). J Arch Sci 37:139-149

Figueiral I, Pomarèdes H, Court-Picon M, Bouby L, Tardy C, Terral JF (2014) New insights into Mediterranean Gallo-Roman farming: a closer look at archaeological wells in Southern France. Archaeol Anthropol Sci. doi:10.1007/s12520-014-0181-8

Foxhall L (1998) Cargoes of the heart's desire: the character of trade in the archaic Mediterranean world. In: Fisher N, Van Wees N (eds) Archaic Greece. New approaches and new evidence, Duckworth, London, pp 295-309

Grassi F, Labra M, Imazio S, Spada A, Sgorbati S, Scienza A, Sala F (2003) Evidence of a secondary grapevine domestication centre detected by SSR analysis. Theor Appl Genet 107:1,315-1,320

Hansen J, Renfrew JM (1978) Palaeolithic-Neolithic seed remains at Franchthi cave, Greece. Nature 271:349-352

Jacquat C, Martinoli D (1999) Vitis vinifera L.: wild or cultivated? Study of the grape pips found at Petra, Jordan, 150 BC-AD 40. Veget Hist Archaeobot 8:25-30

Kučan D (1995) Zur Ernährung und dem Gebrauch von Pflanzen im Heraion von Samos im 7. Jhd v. Chr. Jb DAI 110:1-64

Kučan D (2000) Rapport synthétique sur les recherches archéobotaniques dans le sanctuaire d'Héra de l'île de Samos. Pallas 52:99-108

Kuhl FP, Giardina CR (1982) Elliptic Fourier features of a closed contour. Comput Vision Graph 18:259-278

Lacombe T (2012) Contribution à l'étude de l'histoire évolutive de la vigne cultivée (Vitis vinifera L.) par l'analyse de la diversité génétique neutre et de gènes d'intérêt, Doctoral Thesis, Montpellier SupAgro

Lacombe T, Boursiquot JM, Laucou V, Di Vecchi-Staraz M, Peros JP, This P (2013) Large-scale parentage analysis in an extended set of grapevine cultivars (Vitis vinifera L.). Theor Appl Genet 126:401-414

Levadoux L (1956) Les populations sauvages et cultivées de Vitis vinifera $\mathrm{L}$. Ann de l'Amélioration des Plantes 6:59-117

Mangafa M, Kotsakis K (1996) A new method for the identification of wild and cultivated charred grape seeds. J Arch Sci 23:409-418 
Margaritis E, Jones M (2006) Beyond cereals: crop processing and Vitis vinifera L. Ethnography, experiments and charred grape remains from Hellenistic Greece. J Arch Sci 33:784-805

McGovern PE (2004) Ancient wine: the search for origins of viniculture. Princeton University Press, Princeton

McGovern PE, Glusker DL, Exner LJ, Voigt MM (1996) Neolithic resinated wine. Nature 381:480-481

Miller N (2008) Sweeter than wine? The use of the grape in early Western Asia. Antiquity 82:937-946

Myles S, Boyko AR, Owens CL, Brown CJ, Grassi F, Aradhya MK, Prins B, Reynolds A, Chia JM, Ware D, Bustamante CD, Buckler ES (2011) Genetic structure and domestication history of the grape. Proc Natl Acad Sci USA 108:3,530-3,535

Negrul AM (1946) Origin and classification of cultivated grape. In: Baranov AKY, Lazarevski MA, Palibin TV, Prosmoserdov NN (eds) The Ampelography of the USSR, vol 1. Pischepromizdat, Moscow, pp 159-216

Olmo HP (1995) The origin and domestication of the vinifera grape. In: McGovern PE, Fleming JS, Katz SH (eds) The origins and ancient history of wine (Food and nutrition in history and anthropology series 11). Gordon and Breach, Amsterdam, pp 31-43

Orrù M, Grillo O, Lovicu G, Venora G, Bacchetta G (2013) Morphological characterization of Vitis vinifera L. by image analysis and comparison with archaeological remains. Veget Hist Archaeobot 22:231-242

Picq S (2012) Diversité et évolution chez Vitis vinifera L. de traits impliqués dans le syndrome de domestication et dans la biologie de la reproduction, Doctoral thesis, Université Montpellier 2

Picq S, Santoni S, Lacombe T, Latreille M, Weber A, Ardisson M, Ivorra S, Maghradze D, Arroyo-Garcia R, This P, Terral JF, Bacilieri R (2012) A small XY chromosomal region explains sex determination in wild dioecious grapevines and the reversal to hermaphroditism in domesticated $V$. vinifera $\mathrm{L}$. BMC Plant Biol

Renfrew JM (1966) A report on recent finds of carbonized cereal grains and seeds from Prehistoric Thessaly. Thessalika 5:21-36

Renfrew JM (1989) Carbonized grains and seeds. In: Gimbutas M, Winn S, Shimanbuku D (eds) Achilleion: a Neolithic settlement in Thessaly, Greece, 6400-5600 BC. Institute of Archaeology, UCLA, pp 307-310
Renfrew JM (1995) Palaeoethnobotanical finds of Vitis from Greece. In: McGovern PE, Fleming JS, Katz SH (eds) The origins and ancient history of wine (Food and nutrition in history and anthropology, series 11). Gordon and Breach, Amsterdam, pp 255-267

Sarpaki A (1995) Toumba Balomenou, Chaeronia: plant remains from the early and middle neolithic levels. In: Kroll H, Pasternak M (eds) Res archaeobotanicae. Oetker-Voges, Kiel, pp 281-300

Sefc KM, Lopes MS, Lefort F et al (2000) Microsatellite variability in grapevine cultivars from different European regions and evaluation of assignment testing to assess the geographic origin of cultivars. Theor Appl Genet 100:498-505

Shipley G (1987) A history of Samos. Clarendon Press, Oxford

Smith H, Jones G (1990) Experiments on the effects of charring on cultivated grape seeds. J Arch Sci 17:317-327

Stummer A (1911) Zur Urgeschichte der Rebe und des Weinbaues. Mitt Anthropol Ges Wien 61:283-296

Terral JF, Tabard E, Bouby L, Ivorra S, Pastor T, Figueiral I, Picq S, Chevance JB, Jung C, Fabre L, Tardy C, Compan M, Bacilieri R, Lacombe T, This P (2010) Evolution and history of grapevine (Vitis vinifera) under domestication: new morphometric perspectives to understand seed domestication syndrome and reveal origins of ancient European cultivars. Ann Bot 105:443-455

Terral JF, Newton C, Ivorra S, Gros-Balthazard M, Gros-Balthazard M, de Tito Morais C, Picq S, Tengberg M, Pintaud JC (2012) Insights into the complex historical biogeography of date palm agrobiodiversity (Phoenix dactylifera L.) using geometric morphometrical analysis of modern seeds from various origins and Egyptian ancient material. J Biogeogr 39:929-941

This P, Lacombe T, Thomas MR (2006) Historical origins and genetic diversity of wine grapes. Trends Genet 22:511-519

Valamoti SM, Mangafa M, Koukouli-Chrysanthaki C, Malamidou D (2007) Grape-pressings from northern Greece: the earliest wine in the Aegean? Antiquity 81:54-61

Zohary D (1995) The domestication of the grapevine Vitis vinifera $\mathrm{L}$ in the Near East. In: McGovern PE, Fleming JS, Katz SH (eds) The origins and ancient history of wine (Food and nutrition in history and anthropology, series 11). Gordon and Breach, Amsterdam, pp 23-30

Zohary D, Hopf M, Weiss E (2012) Domestication of plants in the Old World, 4th edn. Oxford University Press, Oxford 